\title{
Revisiting Development Disparities across the Indian States: In Quest of Evidence of Resource Curse
}

Mofidul Hassan ${ }^{+*}$ and M. P. Bezbaruah ${ }^{\hat{\imath}^{*}}$

\section{Abstract}

Despite a large number of studies going into the issue of income and developmental disparities across states in India, the possibility of resource curse being at the root of some states persistently lagging in development has rarely been probed. The present paper is aimed at filling this void in the literature. Economic common sense and writing of some eminent development economists suggest that regions endowed with resources should be in the advantaged position to grow fast and develop quickly. In reality, however, regions endowed richly with natural resources have often tended to lag- a phenomenon that has given rise to the resource curse hypothesis. Countries/regions rich in natural resources can be cursed if the easy and abundant resource revenue breeds moral hazards causing institutional weaknesses that allow rent-seeking and other anti-developmental processes to flourish. In the Indian context, persistent lagging behind of the resource-rich states of Odisha, Madhya Pradesh, Chhattisgarh, Assam, Jharkhand, and Bihar hints at resource curse casting a spell over these states. Using panel data on 17 major Indian states at decennial intervals from 1981 to 2011, evidence for probable resource curse has been explored while controlling for some common determinants of development. Results confirm evidence in support of resource curse dragging overall development attainment in most of the resource-rich states. On a positive note, however, it has been found that development attainment across India has advanced progressively, especially in the post-reform decades.

Keywords: Resource Curse, Development Attainment, Component Index, Composite Index

\footnotetext{
${ }^{+}$Assistant Professor, Department of Economics, Pandit Deendayal Upadhyaya Adarsha Mahavidyalaya, Tulungia Bongaigaon

${ }^{*}$ Corresponding Author, Emails: mofi@gauhati.ac.in and bezbaruah.mp@gmail.com

* Professor, Department of Economics, Gauhati University, Guwahati-781014
} 


\section{Introduction}

India is a large country both in terms of area and population, with a land area of 3.2 million square kilometres, stretching over about $3200 \mathrm{~km}$ from north to south and about $3000 \mathrm{~km}$ from east to west. Topography, climatic conditions, resource endowment, and even culture and traditions of the inhabitants vary enormously across its different regions. In a country of such vast expanse and diversity, it is not surprising to find disparities in socio-economic development attainments across regions. The regional disparity in India has often been a matter of concern. Persistence of regional disparities can find expression in socio-political discontentment in the backward regions leading to disruptions and destabilisation, which in turn can further aggravate the disparity. Such disruption can endanger India's potential of emerging as an economic superpower cashing on its much talked about demographic dividends. Thus, understanding India's regional development disparity and striving for greater regional convergence in development attainments assumes importance. It is therefore not surprising that quite a few analytical works on the subject are found in the literature (Ahluwalia, 2000; Bhattacharya et al. 2004; Das, Ghate and Robertson, 2013; Dhar and Sastry, 1969; Dholakia, 1994; Ghosh, 2008; Kundu 2010; Kurian, 2000; Nair, 1983; Nayyar, 2008; Shetty, 2003; Williamson, 1965), Revisiting the beaten track was felt necessary to explore whether 'resource curse' has had a role in the unevenness in development attainments across regions in India. The issue has not found much attention in the available literature.

A strand of writings on development dynamics tends to theorise that development originates in regions which are endowed with resourcesnatural, human and others (Myrdal, 1957; Krugman, 1991). In reality, however, it is often found that several faster-growing economies/regions had little nature-endowed resource base, whereas many countries/regions richly endowed with natural resources languish in terms of economic performance. Such negative correspondence between resource abundance and economic growth has led to the formulation of the resource curse hypothesis (Auty, 1993). It propounds that regions endowed richly with natural resources tend to lag in development relative to the regions that are not so well endowed. Countries rich in natural resources, such as minerals, are cursed if the easy and abundant resource revenue act as a sort of moral hazard inducing poor quality of institutions, manifested in the dysfunctional legal system, low transparency, widespread rent-seeking, overspending on public service etc. (Auty, 2001; Brunnschweiler and Bulte, 2008; Gelb 1988; Ross 1999 ). A resulting outcome may be a lack of development of the financial system, which in turn makes raising finances for entrepreneurial activity difficult (Beck, 2011). Boschini, Pettersson, and Roine (2007) and Mehlum, Moene, and Torvik (2006) argued that the potential pitfall of the resource curse could be countered by good institution quality. Acemoglu, Johnson, and Robinson (2002) cite evidence of the curse being reversed in the presence of higher institutional quality.

In the Indian context, states like Odisha, Madhya Pradesh, Chhattisgarh, Assam, Jharkhand, and Bihar, all richly endowed with natural resources, have persistently lagged in terms of levels and growth of per capita income, while states like Maharashtra, not as well-endowed, have remained at the forefront in this regard. The present paper is an attempt to investigate if the developmental backlog in the former group of states can be ascribed to the resource curse.

The study covers seventeen major Indian states of India- Andhra Pradesh (including Telangana), Assam, Bihar (including Jharkhand), Gujarat, Haryana, Himachal Pradesh, Jammu \& Kashmir, Karnataka, Kerala, Madhya Pradesh (including Chhattisgarh), Maharashtra, Odisha, Punjab, Rajasthan, Tamil Nadu, Uttar Pradesh and West Bengal. These 17 states jointly account for $90 \%$ (as per 2011 census) of the total population of India and $89 \%$ of India's total land area. The small but highly developed states like Delhi and Goa are not included because their development 
processes are not comparable with the other states of the country. For the other excluded states, the necessary data are not available for the reference time points of the study. The study relates to the period from 1981 to 2011 . The terminal year corresponds to the latest population census from which critical population data has been used in the study. Since typically studies on Indian economy tend to compare the pre and post-reform experiences, it was necessary to go back at least by ten years before the launching of the economic reforms ${ }^{1}$ in 1991. The specific objectives pursued in the present paper are: (a) to examine the pattern of regional disparities in development attainment in India and (b) to identify the factors which correspond to the observed pattern of regional disparities. As indicated above, the underlying research question is whether persistent lagging of the bunch of resource-rich states can be ascribed to 'resource curse'.

The paper is organised into four sections. Section two outlines the database and analytical framework. Results have been presented and discussed in section three. Principal findings of the exercise have been summarised in the concluding section.

\section{Materials, Methods and Models}

\section{Data Source}

The study is based on secondary data. Data regarding income indicators - per capita net state domestic product, state wise share of GDP by industry of origin; poverty, health indicators - life expectancy at birth, state wise number of hospital beds and educational indicators literacy, state wise number of total schools, crime rate, state wise total population have been taken from the Census of India, Central Statistical Office (CSO), Planning Commission, Registrar General of India, Central Bureau of Health Intelligence (CBHI), Economic Surveys of Ministry of Finance, All India School Education

\footnotetext{
${ }^{1}$ Following a balanced of payment crisis in 1991, India embarked upon a far reaching economic reform agenda which resulted in replacement of the physical control based economic policy regime of the previous 40 years by a more market oriented system. The reform process primarily consisted of dereservation of most of the
}

Survey, statistics of school education published by Ministry of Human Resource Development (MHRD), National Crime Bureau Reports, Reserve Bank of India publications- RBI bulletin, Directorate of Economics and Statistics of State Governments and Ministry of Road, Transport \& Highways.

\section{Methodology for Measuring Development Attainment}

A development index has been constructed for combining attainments of the states in different dimensions of development. Broadly the UNDPHDI methodology has been used but with an improvisation. Besides life expectancy at birth, literacy rate, and per capita income, the poverty Head Count Ratio (HCR) has also been incorporated in the index. The rationale for extending the measure lies in the fact that irrespective of the mean level of income in a state, the condition of living of those at the lower end of income distribution is an essential indicator of the level of development. Higher the poverty HCR, more significant is the proportion of the population deprived of the basic minimum standard of living and therefore, lower is the overall development of the state.

Since the four components -per capita NSDP, poverty headcount ratio, literacy rate and life expectancy at birth have different units and scale; these indicators need to be normalised before they can be combined into a composite index. This has been done by using UNDP's Human Development Index (HDI) methodology, which was also suggested by lyengar and Sudarshan (1982). They (1982) further pointed out that it is important to identify the direction of the relationship between the indicators and development attainment before getting down to the normalisation process. While some indicators are positively related to the level of development attainment, others may have a negative association with the level.

industries earlier kept exclusively reserved for the public sector, liberalisation of the private sector from elaborate licensing requirements, internationally floating the Indian rupee and opening up the economy externally for freer trade and capital movement. 
Let $X_{\text {is }}$ represent the size / value of the $\mathrm{i}$-th development indicator in the $s$-th state $(i=$ $1,2,3,4 ; s=1,2 \ldots .17)$. If $X_{\text {is }}$ a positive indicator of development, its normalised values can be obtained as :

$$
\mathrm{I}_{\text {is }}=\left(\mathrm{X}_{\mathrm{is}}-\operatorname{Min}_{\mathrm{s}} \mathrm{X}_{\mathrm{is}}\right) /\left(\operatorname{Max}_{\mathrm{s}} \mathrm{X}_{\mathrm{is}}-\operatorname{Min}_{\mathrm{s}} \mathrm{X}_{\mathrm{is}}\right)
$$

Where $\operatorname{Min}_{s} X_{\text {is }}$ and $\operatorname{Max}_{s} X_{i s}$ are the minimum and maximum of $X_{i s}$, respectively. It is clear that all these scores will lie between 0 and 1 . The value 1 will correspond to that state with maximum value, and 0 will correspond to the state with the minimum value.

However, if $X_{\text {is }}$ is negatively associated with development (e.g., the poverty headcount ratio in the present case), the equation for the component index is expressed as

$$
\mathrm{I}_{\text {is }}=\left(\operatorname{Max}_{\mathrm{s}} \mathrm{X}_{\text {is }}-\mathrm{X}_{\text {is }}\right) /\left(\operatorname{Max}_{\mathrm{s}} \mathrm{X}_{\text {is }}-\operatorname{Min}_{s} \mathrm{X}_{\mathrm{is}}\right)
$$

The functional correspondence between the component indicators and the composite

\begin{tabular}{|c|c|c|}
\hline Component & Indicator & $\begin{array}{l}\text { Functional Relationship with } \\
\text { Development Attainment }\end{array}$ \\
\hline Income & $\begin{array}{l}\text { Per Capita Net State Domestic } \\
\text { Product (PCNSDP) }\end{array}$ & Positive \\
\hline Poverty & Poverty Head Count Ratio (PHCR) & Negative \\
\hline Education & Literacy Rate (LR) & Positive \\
\hline Health & Life Expectancy at Birth (LEB) & Positive \\
\hline
\end{tabular}
development index are summarised in Table 1.
Accordingly, the indices for Life Expectancy at Birth (LEB) and Literacy Rate (LR) have been directly calculated using equation (1) and the index for Poverty Head Count Ratio (PHCR) by using equation (2).

As per the above discussion, the component index for Per Capita Net State Domestic Product (PCNSDP) should also be calculated by using equation (1). However, before applying the formula, the PCNSDP figures have been transformed by taking their natural logarithm. The idea behind this transformation is that the contribution of income to human development

\begin{tabular}{|c|c|c|c|}
\hline Component & Indicator & Maximum Value & Minimum Value \\
\hline Income & $\begin{array}{c}\text { Per Capita Net State Domestic } \\
\text { Product (PCNSDP) (In Rs.) at } \\
\text { 1993-94 prices }\end{array}$ & $\begin{array}{c}32161 \\
\text { (Maharasthra, } \\
\text { 2011-12) }\end{array}$ & $\begin{array}{c}3363 \\
\text { (Bihar,1980-81) }\end{array}$ \\
\hline $\begin{array}{l}\text { Income } \\
\text { Poverty }\end{array}$ & $\begin{array}{l}\text { Poverty Head Count Ratio } \\
\text { (PHCR) }\end{array}$ & $\begin{array}{c}65.29 \\
\text { (Odisha,1983-84) }\end{array}$ & $\begin{array}{c}6.12 \\
\text { (Punjab,1999-2000) }\end{array}$ \\
\hline Education & Literacy Rate (LR) & 100 & 0 \\
\hline Health & $\begin{array}{l}\text { Life Expectancy at Birth } \\
\text { (LEB) (In Years) }\end{array}$ & $\begin{array}{c}74.8 \\
\text { (Kerala,2009-13) }\end{array}$ & $\begin{array}{c}50.0 \\
(U P, 1981-85)\end{array}$ \\
\hline
\end{tabular}
does not increase proportionately but increases at a decreasing rate (United Nations Development Programme 2010). Logarithmic transformation takes into account this idea. Thus the PCNSDP index has been obtained using the formula:

$I_{p c, s}=\left(\right.$ In PCNSDP $_{s}-$ In Min PCNSDP $) /$ (In Max PCNSDP $_{S}$ - In Min PCNSDP P $^{----(3)}$

Where In stands for natural logarithm, and the suffix pc indicate per capita income.

The minimum and maximum values used to calculate the normalised scores of the indicators are given in Table 2 . 
Having obtained the component indices, the composite index of development attainment for the states at any given time thus be computed using the formula

$D I_{s t}=(1 / 4)\left(I_{1 s t}+I_{2 s t}+I_{3 s t}+I_{4 s t}\right)$

The additional suffix $t$ now indicates the point of time.

As in the present study there are 4 component indicators, 17 states, and 4 time points, i takes values 1, 2, 3 and 4 for the four indicators, and $\mathrm{s}$ takes the values from 1 to 17 corresponding to states arranged in alphabetical order, and t takes the values 1, 2, 3 and 4 for the years 1981, 1991, 2001 and 2011 respectively.

\section{Modelling the Panel Data for Explaining Developmental Disparities}

For identification of factors which have had a significant role in differentiated development experience of the states of India, a Panel Data regression has been estimated. The modelling process is delineated as the following:

\section{The Dependent Variable}

The dependent variable for the regression analysis is simply the composite development index $D_{\text {st }}$ where $s$ goes from 1 to 17 for the states included in the study and t goes from 1 to 4 for the years 1981, 1991, 2001 and 2011

\section{Probable Explanatory Factors and Corresponding Explanatory Variables}

The focus of the present exercise is the examination of the evidence of the resource curse; the prime independent variable is the resource endowment status of the states. To control for interferences of other factors such as the state of infrastructure, institutional quality, and geographical conditions, suitable control variables have been defined and included.

\footnotetext{
2 Ratio of GSDP originating from Mining and Quarrying in 2011-12 to population of 2011in these six states is $9 \%$ or more, whereas the ratio is $5 \%$ or less for the other eleven states included in the study. Further, the average share of Mining and Quarrying in the GSDP of the first category of states in the four reference years of the study is $6 \%$ or
}

\section{Resource Richness}

The abundance of the natural resource of a state has been captured in terms of its richness in mineral resources. The richness of a state in mineral resources can be seen in terms of the percentage share of Mining and Quarrying sector in its Gross State Domestic Product (GSDP) and/or, indeed more appropriately, in terms of its GSDP originating in the mining and quarrying sector per thousand of its population. As per these criteria, Odisha, Madhya Pradesh (including Chhattisgarh), Rajasthan, Assam, Gujarat and Bihar (including Jharkhand) have been identified as resource-rich. ${ }^{2}$ To indicate whether a state is resource rich or not, a dummy variable $R_{i}$ has been used, which takes the value 1 for the six resource-rich states and 0 for the other states. In the regression of the composite index of development attainment of the state's $\mathrm{Dl}_{\mathrm{it}}$, a significant negative coefficient of Ri will indicate that given other things, the states in resource-rich category lag behind the others in development attainment.

\section{Infrastructure}

Infrastructure being a multi-dimensional notion, a large number of indicators can be included to capture it. This research is limited to three basic components of infrastructure which are directly related to the component indices going into our composite development index. These are general physical infrastructure, health infrastructure and educational infrastructure.

Road connectivity has been taken as the representative for general physical infrastructure. Road connectivity in a state has been measured as road length per square kilometre of geographical area. The number of hospital beds per thousand of the population in 1981, the base year for the study, has been taken as the indicator of health infrastructure. Educational infrastructure has been captured by the number of school per thousand populations

more while the same value for the second category of states is $3 \%$ or less. As per both the criteria, there is a significant discontinuous gap in the ratio between the states categorised as resource-rich and the group of the other states. 
in the age group 0-14 years in the year 2011. ${ }^{3}$ The infrastructure variables have been normalised by using the formula given in equation (1) to obtain the variables, $\mathrm{Pl}_{i t}, \mathrm{Hl}_{i t}$ and $\mathrm{El}_{\text {it }}$ and representing indices of physical infrastructure, health infrastructure and educational infrastructure respectively. The minimum and maximum values of the basic infrastructure variables underlying these three infrastructure indices are given in Appendix 1.

Governance

Governance is often cited as a critical factor and a summary indicator of institutional factors that significantly impact development outcome. To capture governance, we make the reasonable assumption that better the governance lower will be the incidence of crimes. Following this assumption, the governance variable has been defined as the inverse of the crime rate. Given the structure of the data on crimes published by the National Crime Records Bureau, we define the crime rate in a state as

$$
\mathrm{CR}=\frac{\text { share of the state to total reported cognisable crimes in India }}{\text { share of the state in the total population of India }}
$$

Accordingly, governance in the $\mathrm{i}^{\text {th }}$ state at the $\mathrm{t}^{\text {th }}$ point of time has been measured as

$$
\mathrm{G}_{\text {it }}=1 / \mathrm{CR}_{\text {it }}
$$

\section{Interaction of Resource Richness (R) and Governance (G)}

In the context of the present study, it is important to note that whether resource richness will be a curse or a boon depends to a great extent on the strength of its institutions (Acemoglu, Johnson and Robinson, 2002), in particular, governance. To capture the possible combined effect of governance and resource richness, an interaction term defined as the product of the resource variable and the governance variable (RG) has also been included.

\section{Geography}

Geography is also cited in the literature as a determining factor in development attainment of a region (Krugman, 1991). In the Indian context, the coastal region has been said to have had a greater economic advantage, especially in the post-reform period. Such states have attracted the lion's share of Foreign Direct Investment inflow to the country. To capture this geographical characteristic, the dummy variable " $C$ " is used, which takes the value 1 for the coastal states $\& 0$ for the others. The expected sign of the coefficient of $C$ is positive.

\footnotetext{
${ }^{3}$ Ideally the indicator should have been the number of schools per thousand of the population in the age group 0 to 14 in the base year 1981. However, the population of the required age group could not be extracted from the
}

\section{Functional Specification and Estimation Procedure}

In light of the above discussion, the basic functional relationships can be written as

$$
D I_{s t}=F\left(R_{s}, P I_{s t}, E l_{s t}, H I_{s t}, G_{s t}, R_{s} G_{s t}, C_{s}\right)
$$

The dependent variable $Y_{s t}$ being an index lying between 0 and 1 , a linear specification for the function (5) will not be appropriate. Because the predicted values from a linear regression equation will not be necessarily contained between 0 and 1 . Hence a logistic functional form for the relation (5) has been adopted. Thus $\mathrm{DI}_{\text {st }}$ has been modelled as-

$$
\mathrm{DI}_{\mathrm{st}}=\frac{1}{1+e^{-Z s t}}
$$

Where $Z_{\text {st }}$ is a linear combination of explanatory variables and a random disturbance $U_{\text {st. }}$.

$$
\begin{gathered}
Z_{s t}=\alpha+\zeta R_{s}+\beta P I_{s t}+\gamma E I_{s t}+\delta H I_{s t}+\theta G I_{s t}+ \\
\eta C_{s}+\partial R_{s} G_{s t}+U_{s t}------(7)
\end{gathered}
$$

Combining equations (6) and (7) we obtain the following linear equation of the constructed dependent variable $\operatorname{Ln}\left\{D I_{s t} /\left(1-D I_{s t}\right)\right\}$

1981 Census data. Accordingly, the denominator for the ratio has been taken as the population in the relevant age group in the terminal year 2011. 
$\operatorname{Ln}\left\{D I_{s t} /\left(1-D I_{s t}\right)\right\}=Z_{s t}=\alpha+\zeta R_{s}+\beta P I_{s t}+\gamma \mathrm{EI}_{s t}+\delta H I_{s t}+$ $\theta G I_{s t}+\eta C_{s}+\partial R_{s} G_{s t}+U_{s t}$

As Hausman test rejected the random effect model formulation, the fixed effect model was adopted $^{4}$ for estimation. The White test was carried out to check for the presence of heteroscedasticity. ${ }^{5}$ The test did not reject homoscedasticity. Accordingly, the model was found to be estimable by Ordinary Least Square method. The Least Square Dummy Variable model came across as a suitable formulation for the panel regression (Gujarati and Sangeetha, 2007). Since the two dummy explanatory variables, $R_{i}$ and $C_{i}$ in the function already classify the states on the criteria of resource endowment and locational consideration, additional dummies for the states was felt to be superfluous. Hence, the estimated equation has been formulated as a time fixed effect model using time dummies rather than state fixed effect model. Accordingly, the model finally estimated is of the form outlined in equation 9.

$\ln \left\{D I_{s t} /\left(1-D I_{s t}\right)\right\}=Z_{s t}=\alpha+\zeta R_{s}+\beta P I_{s t}+\gamma E_{s t}+\delta H_{s t}+$ $\theta G I_{s t}+\eta C_{s}+\partial R_{s} G_{s t}+\Omega T_{2}+f T_{3}+€ T_{4}+u_{i t}$

Inclusion of the time dummies also has the additional advantage of observing the extent to which development attainment across states, in general, improved over time.

\section{Results and Discussion}

\section{Development Attainment Across the Indian States}

The values of the component indices calculated for the 17 states for the four different time points of 1981, 1991, 2001 and 2011 are kept in the Appendix. The values of the Composite Index of development Attainment for the states in all four-time points along with their ranks are presented in Table 3.

\section{Factors Behind Variations in Development Attainment Across States}

The results of the panel data regression estimated for identification of statistically

\footnotetext{
${ }^{4}$ Hausman test for $\mathrm{H}_{\mathrm{o}}$ : Random Effect is appropriate, against $\mathrm{H}_{\mathrm{a}}$ : Fixed Effect is appropriate gave $\mathrm{Chi}^{2}(4)=$ 216.26 with Prob> $\mathrm{Chi}^{2}=0.0000$
}

significant factors contributing to disparities in development attainments across the states of India are presented in Table 4.

The explanatory variable of primary interest of the study, $R_{i}$ has come out statistically significant with the expected negative sign. This result confirms that a resource curse process has been at work in the Indian development experience of the reference period of the study. The coefficient of health infrastructure being statistically highly significant with a positive sign implies that the condition of health infrastructure in the states has played a crucial role in their developmental outcome.

The constant term in a regression model captures the mean effect on the dependent variable of the factors not explicitly included in the model. The constant being significant in the estimated model implies that, apart from the variable explicitly included as explanatory variables, other significant factors are contributing to the formation of the dependent variable. Identification of such factors and capturing of their influence explicitly in the empirical model would, of course, require further research on the subject.

A heartening feature of the result presented in Table 4 is that the coefficients of the three-time dummies are all statistically significant. This implies that compared to the base year of 1981, development attainment levels across states, in general, have progressively improved in the subsequent three decades. Indeed, the coefficient of the time dummy for 2001 is greater than that for 1991 and the one for 2011 being greater than that for 2001 imply that development attainments across India have been rising not just steadily but at an increasing pace in the decades since the introduction of economic reforms in 1991.

\footnotetext{
${ }^{5}$ White's test for $\mathrm{H}_{\mathrm{o}}$ : homoscedasticity against $\mathrm{H}_{\mathrm{a}}$ : unrestricted heteroskedasticity gave $\mathrm{Chi}^{2}(25)=19.76$ Prob $>\mathrm{Chi}^{2}=0.7592$
} 


\begin{tabular}{|c|c|c|c|c|c|c|c|c|}
\hline \multirow[t]{3}{*}{ States } & \multirow{2}{*}{\multicolumn{2}{|c|}{1981}} & \multirow{2}{*}{\multicolumn{2}{|c|}{1991}} & \multirow{2}{*}{\multicolumn{2}{|c|}{2001}} & \multirow{2}{*}{\multicolumn{2}{|c|}{2011}} \\
\hline & & & & & & & & \\
\hline & Value & Rank & Value & Rank & Value & Rank & Value & Rank \\
\hline Andhra Pradesh & 0.3839 & 8 & 0.4968 & 7 & 0.6426 & 9 & 0.7893 & 8 \\
\hline Assam & 0.2692 & 13 & 0.3521 & 13 & 0.4426 & 15 & 0.5687 & 15 \\
\hline Bihar & 0.1249 & 17 & 0.2550 & 17 & 0.3837 & 17 & 0.5405 & 17 \\
\hline Gujarat & 0.4033 & 6 & 0.5380 & 5 & 0.7035 & 5 & 0.8310 & 7 \\
\hline Haryana & 0.4748 & 3 & 0.5802 & 3 & 0.7387 & 3 & 0.8393 & 6 \\
\hline Himachal Pradesh & 0.4228 & 5 & 0.4915 & 9 & 0.6852 & 7 & 0.8548 & 5 \\
\hline Jammu \& Kashmir & 0.3932 & 7 & 0.4683 & 10 & 0.6117 & 12 & 0.7383 & 11 \\
\hline Karnataka & 0.3836 & 9 & 0.4921 & 8 & 0.6628 & 8 & 0.7721 & 10 \\
\hline Kerala & 0.5466 & 2 & 0.7050 & 1 & 0.8196 & 1 & 0.9455 & 1 \\
\hline Madhya Pradesh & 0.2014 & 14 & 0.2969 & 16 & 0.4692 & 13 & 0.6071 & 13 \\
\hline Maharashtra & 0.4507 & 4 & 0.5751 & 4 & 0.7096 & 4 & 0.8762 & 2 \\
\hline Odisha & 0.1353 & 16 & 0.2980 & 15 & 0.4049 & 16 & 0.5904 & 14 \\
\hline Punjab & 0.5534 & 1 & 0.6912 & 2 & 0.7856 & 2 & 0.8622 & 3 \\
\hline Rajasthan & 0.2698 & 12 & 0.4177 & 12 & 0.6180 & 11 & 0.7268 & 12 \\
\hline Tamil Nadu & 0.3144 & 10 & 0.5170 & 6 & 0.6920 & 6 & 0.8597 & 4 \\
\hline Uttar Pradesh & 0.1739 & 15 & 0.3161 & 14 & 0.4527 & 14 & 0.5671 & 16 \\
\hline West Bengal & 0.2846 & 11 & 0.4642 & 11 & 0.6341 & 10 & 0.7747 & 9 \\
\hline
\end{tabular}

\begin{tabular}{|c|c|c|}
\hline Variables, etc. & $\begin{array}{c}\text { Estimated Coefficient } \\
\text { /Values }\end{array}$ & t-values \\
\hline Resource (R) & $-0.4657722 * *$ & -2.25 \\
\hline Physical Infrastructure (PI) & -0.1158613 & -0.24 \\
\hline Education Infrastructure (EI) & 0.1013584 & 0.25 \\
\hline Health Infrastructure (HI) & $2.140257^{* * *}$ & 6.60 \\
\hline Governance (G) & 0.0079367 & 0.09 \\
\hline Governance Resource Interaction (GR) & -0.0780512 & -0.57 \\
\hline Whether Coastal State (C) & -0.0885664 & -0.83 \\
\hline Time Dummy for $1991\left(T_{2}\right)$ & $0.4509387^{* * *}$ & 3.34 \\
\hline Time Dummy for $2001\left(T_{3}\right)$ & $1.039051^{* * *}$ & 7.37 \\
\hline Time Dummy for $2011\left(T_{4}\right)$ & $1.56122^{* * *}$ & 9.03 \\
\hline Constant & $-0.7488045^{* * *}$ & -4.25 \\
\hline $\mathbf{R}^{2}$ & 0.8652 & \\
\hline$F(10,57)$ & $36.58^{* * *}$ & \\
\hline
\end{tabular}




\section{Conclusion}

It is heartening to find that states across India improved their levels of development during the reference period of the study 1981-2011. Moreover, the improvements have been at higher rates in the post-reform (post-1991) decades. Yet, the fact remains that the mineralrich states of Odisha, Bihar (including Jharkhand), Madhya Pradesh (including Chhattisgarh), Rajasthan and Assam continued to occupy lower places in development ranking during the period. This points towards the operation of the resource curse phenomenon in these states. The statistically significant negative coefficient of the dummy for resource-rich states in the panel regression of Composite Development Index more rigorously confirms its presence.

Scholars -Acemoglu, Johnson and Robinson (2002) argue that the resource curse can be avoided and even turned into a boon if strong and right institutions are put in place. Even within India, there is the striking example of Gujarat, which despite falling in the resourcerich category, achieved and maintained a remarkable development attainment rank (Refer to Table 3 above). Reports of a number of different agencies (Mundle et al., 2012; 2016 and KMPG, 2015) demonstrate that Gujarat consistently ranks higher among Indian states in terms of the effectiveness of business promoting institutions. In contrast, other resource-rich states like Assam and Bihar have not only lagged in terms of development attainment but also been occupying a much lower rank in terms of criterion such as ease of doing business. In order to turn their gifted nature resources from bane to boon, it will be necessary to strengthen enabling institutions in these states.

\section{References}

Acemoglu, D., Johnson, S., \& Robinson, J.A. (2002). Reversal of Fortune: Geography and Institutions in the Making of the Modern World Income Distribution. Quarterly Journal of Economics, 117, 1231-1294.
Ahluwalia, M. S., (2000). Economic Performance of states in Post-reforms Period. Economic and Political Weekly, 35(19), 1637-1648.

Auty, R.M., (1993). Sustaining development in resource economies: the resource curse thesis. London: Rutledge.

Auty, R.M., (2001). The political economy of resource-driven growth. European Economic Review, 45(4), 839-846.

Beck, T., (2011). Finance and Oil: Is there a resource curse in financial development? Discussion Paper, (2011-017). Tilburg University: Center for Economic Research.

Bhattacharya, B. B., \& Sakthivel, S. (2004). Regional Growth and Disparity in India: Comparison of Pre- and Post-Reform Decades. Economic and Political Weekly, 39(10), 1071-1077.

Boschini, A. D., Pettersson, J., \& Roine, J., (2007). Resource Curse or Not: A Question of Appropriability. Scandinavian Journal of Economics, 109(3), 593-617.

Brunnschweiler, C. N., \& Bulte, E. H. (2008). The Resource Curse Revisited and Revised: A Tale of Paradoxes and Red Herrings. Journal of Environmental Economics and Management, 55(3), 248-264.

Das, S., Ghate, C., \& Robertson, E. P. (2013). Remoteness and Unbalanced Growth: Understanding Divergence across Indian Districts (Working Paper No. 268). New Delhi: Indian Council for Research on International Economic Relations.

Dhar, P.N., \& Sastry, D.U. (1969). Interstate variations in Industry, 1951-61. Economic and Political Weekly, 4(31), 535-38.

Dholakia, R., (1994). Spatial Dimension of Acceleration of Economic Growth in India. Economic and Political Weekly, 29(35), 23032309.

Gelb, A. H. (1988). Oil Windfalls: Blessing or curse? New York: Oxford University Press.

Ghosh, M. (2008). Economic Growth and Regional Convergence. In Economic Reforms and 
Indian Economic Development: Selected Essays. New Delhi: Bookwell Publications.

Gujarati, D. N., \& Sangeetha. (2007). Basic Econometrics (Fourth ed.). New Delhi: Tata McGraw Hill Eduaction Private Limited, 656.

Iyengar, N. S., \& Sudarshan, P. (1982). A Method of Classifying Regions from Multivariate Data. Economic and Political Weekly, 17(51), 2047-2052.

KMPG. (2015, September). Assessment of State Implementation of Business Reforms. Retrieved from

https://www.kpmg.com/IN/en/IssuesAndInsigh ts/ArticlesPublications/Documents/State-

Assessment-Report.pdf

Krugman, P. (1991), Geography and Trade. Cambridge, MA: MIT Press.

Kundu, A., \& Varghese, K., (2010). Regional Inequality and Inclusive Growth in India under Globalisation, New Delhi: Oxfam India working paper series, September 2010.

Kurian, N.J. (2000).Widening Regional Disparities in India - Some Indicators. Economic and Political Weekly,35(7), 736-743.

Mehlum, H., Moene, K. \& Torvik, R. (2006). Institutions and the Resource Curse. The Economic Journal, 116(508), 1-20.

Mundle, S., Chakraborty, P., Choudhury, S., \& Sikdar, S. (2012). The Quality of Governance:
How Have Indian States Performed?(Working paper No. 2012-104). New Delhi: National Institute of Public Finance and Policy. http://www.nipfp.org.in

Mundle, S., Chakraborty, P., Choudhury, S., \& Sikdar, S. (2016). Governance Performance of Indian States: Changes between 2001-02 and 2011-12. Economic \& Political Weekly, 51(36).

Myrdal, G. (1957). Economic Theory and Underdeveloped Regions. London: Duckworth.

Nair, K.R.G., (1983). Inter-state Income Differentials in India: $1970-71$ to $1979-80$. Man and Development, 5 (2).

Nayyar, G (2008). Economic Growth and Regional Inequality in India. Economic and Political Weekly, 43(6).

Ross, M. L., (1999). The political economy of the resource curse. World Politics, 51(2), 297-322.

Shetty, S.L., (2003). Growth of SDP and Structural Changes in State Economies, Interstate Comparison. Economic and Political Weekly, 38(49), 5189-5200.

United Nations Development Programme, (2010). Human Development Report 2010, New York: Palgrave Macmillan, 216.

Williamson, J. G. (1965). Regional Inequality and Process of National Development: A Description of the Patterns. Economic Development and Cultural Change, 13(4), 2-84.

\section{Appendix}

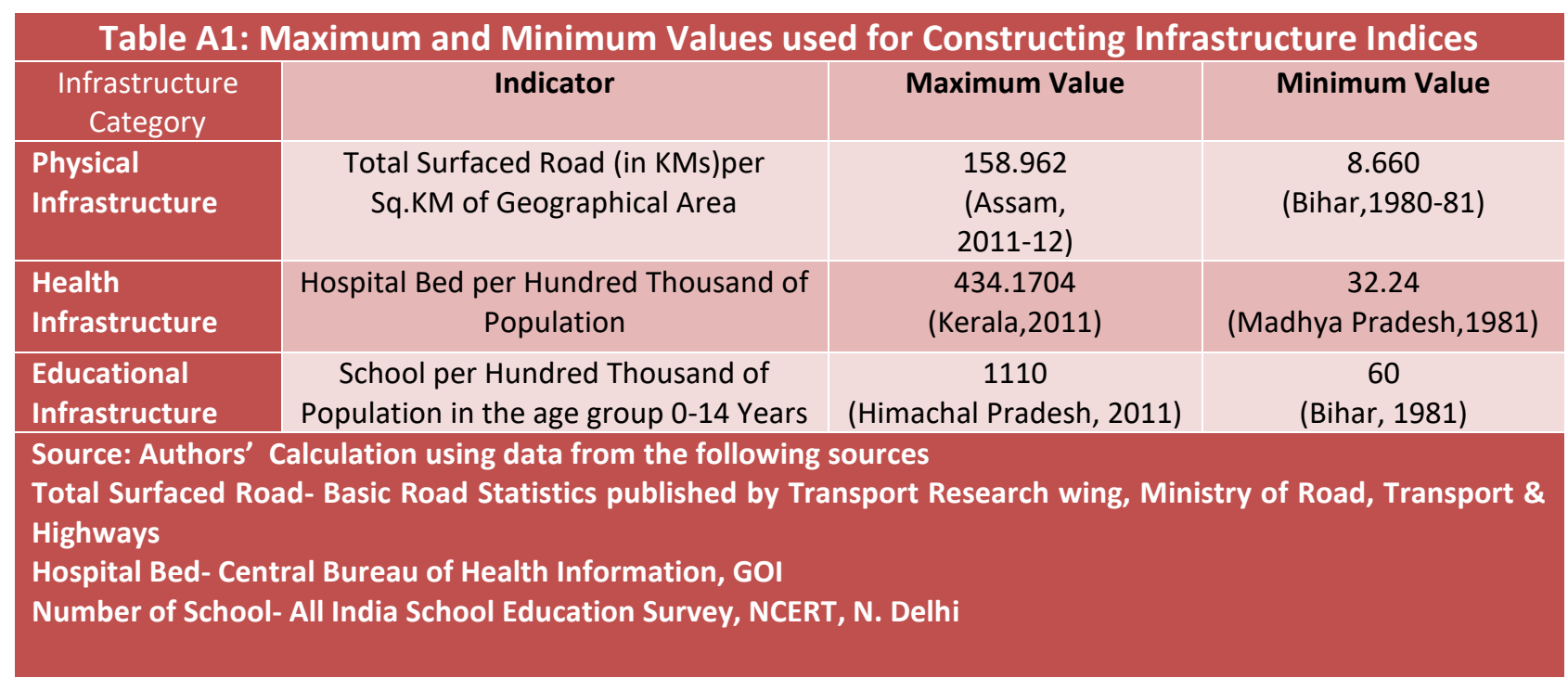




\begin{tabular}{|l|c|c|c|c|}
\hline \multicolumn{5}{|c}{ Table A2: The Values of the Component Indices for the Year 1981 } \\
\hline State & PCNSDP & Literacy Rate & Poverty & LEB \\
\hline Andhra Pradesh & 0.215 & 0.3566 & 0.625 & 0.33871 \\
\hline Assam & 0.140 & 0.4341 & 0.427 & 0.076613 \\
\hline Bihar & 0.000 & 0.33 & 0.053 & 0.116935 \\
\hline Gujarat & 0.299 & 0.4492 & 0.559 & 0.306452 \\
\hline Haryana & 0.358 & 0.3713 & 0.755 & 0.415323 \\
\hline Himachal Pradesh & 0.241 & 0.4248 & 0.840 & 0.185484 \\
\hline Jammu \& Kashmir & 0.274 & 0.3064 & 0.706 & 0.28629 \\
\hline Karnataka & 0.176 & 0.4621 & 0.465 & 0.431452 \\
\hline Kerala & 0.228 & 0.7885 & 0.427 & 0.741935 \\
\hline Madhya Pradesh & 0.105 & 0.37 & 0.267 & 0.064516 \\
\hline Maharashtra & 0.424 & 0.5724 & 0.375 & 0.431452 \\
\hline Odisha & 0.084 & 0.3362 & 0.000 & 0.120968 \\
\hline Punjab & 0.408 & 0.4337 & 0.844 & 0.528226 \\
\hline Rajasthan & 0.107 & 0.3011 & 0.530 & 0.141129 \\
\hline Tamil Nadu & 0.201 & 0.5439 & 0.234 & 0.278226 \\
\hline Uttar Pradesh & 0.056 & 0.3265 & 0.313 & 0 \\
\hline West Bengal & 0.174 & 0.4865 & 0.179 & 0.298387 \\
\hline Source: Authors' calculation using data from the following sources & \\
\hline Per Capita Net State Domestic Product (PCNSDP)- Central Statistical Office (CSO) website,
\end{tabular}

\begin{tabular}{|l|c|c|c|c|}
\hline \multicolumn{5}{|c}{ Table A3: The Values of the component indices for the year 1991 } \\
\hline State & PCNSDP & Literacy Rate & Poverty & LEB \\
\hline Andhra Pradesh & 0.330 & 0.4408 & 0.741 & 0.475806 \\
\hline Assam & 0.230 & 0.5289 & 0.420 & 0.229839 \\
\hline Bihar & 0.083 & 0.3847 & 0.178 & 0.375 \\
\hline Gujarat & 0.390 & 0.6129 & 0.706 & 0.443548 \\
\hline Haryana & 0.530 & 0.5585 & 0.692 & 0.540323 \\
\hline Himachal Pradesh & 0.356 & 0.6386 & 0.527 & 0.443548 \\
\hline Jammu \& Kashmir & 0.275 & 0.4123 & 0.670 & 0.516129 \\
\hline Karnataka & 0.352 & 0.5604 & 0.552 & 0.504032 \\
\hline Kerala & 0.313 & 0.8981 & 0.685 & 0.923387 \\
\hline Madhya Pradesh & 0.165 & 0.442 & 0.391 & 0.189516 \\
\hline Maharashtra & 0.566 & 0.6487 & 0.489 & 0.596774 \\
\hline Odisha & 0.151 & 0.4909 & 0.288 & 0.262097 \\
\hline Punjab & 0.566 & 0.5851 & 0.920 & 0.693548 \\
\hline Rajasthan & 0.268 & 0.3855 & 0.651 & 0.366935 \\
\hline Tamil Nadu & 0.385 & 0.6266 & 0.520 & 0.53629 \\
\hline Uttar Pradesh & 0.163 & 0.4071 & 0.420 & 0.274194 \\
\hline West Bengal & 0.283 & 0.577 & 0.509 & 0.487903 \\
\hline Source: As Stated in the Above Table A2 & & & \\
\hline
\end{tabular}




\begin{tabular}{|l|r|r|r|r|}
\hline \multicolumn{5}{|c}{ Table A4: The Values of the Component Indices for the Year 2001} \\
\hline States & PCNSDP & Literacy Rate & Poverty & LEB \\
\hline Andhra Pradesh & 0.510 & 0.6047 & 0.851 & 0.604839 \\
\hline Assam & 0.265 & 0.6325 & 0.502 & 0.370968 \\
\hline Bihar & 0.086 & 0.486 & 0.390 & 0.572581 \\
\hline Gujarat & 0.609 & 0.6914 & 0.880 & 0.633065 \\
\hline Haryana & 0.639 & 0.6791 & 0.972 & 0.665323 \\
\hline Himachal Pradesh & 0.562 & 0.7648 & 0.728 & 0.685484 \\
\hline Jammu \& Kashmir & 0.349 & 0.5552 & 0.897 & 0.645161 \\
\hline Karnataka & 0.558 & 0.6664 & 0.778 & 0.649194 \\
\hline Kerala & 0.515 & 0.9086 & 0.903 & 0.951613 \\
\hline Madhya Pradesh & 0.367 & 0.6397 & 0.479 & 0.391129 \\
\hline Maharashtra & 0.652 & 0.7688 & 0.692 & 0.725806 \\
\hline Odisha & 0.241 & 0.6308 & 0.312 & 0.435484 \\
\hline Punjab & 0.671 & 0.6965 & 1.017 & 0.758065 \\
\hline Rajasthan & 0.424 & 0.6041 & 0.859 & 0.584677 \\
\hline Tamil Nadu & 0.581 & 0.7345 & 0.759 & 0.693548 \\
\hline Uttar Pradesh & 0.226 & 0.5627 & 0.587 & 0.435484 \\
\hline West Bengal & 0.499 & 0.6864 & 0.658 & 0.693548 \\
\hline Source: As Stated & & & \\
\hline
\end{tabular}

Source: As Stated in the Above Table A2

\begin{tabular}{|l|r|r|r|r|}
\hline \multicolumn{5}{|c|}{ Table A5: The Values of the Component Indices for the Year 2011} \\
\hline States & PCNSDP & LR & Poverty & LEB \\
\hline Andhra Pradesh & 0.801 & 0.67 & 0.964 & 0.721774 \\
\hline Assam & 0.444 & 0.722 & 0.572 & 0.53629 \\
\hline Bihar & 0.277 & 0.629 & 0.543 & 0.71371 \\
\hline Gujarat & 0.974 & 0.78 & 0.837 & 0.733871 \\
\hline Haryana & 0.938 & 0.756 & 0.930 & 0.733871 \\
\hline Himachal Pradesh & 0.802 & 0.828 & 0.983 & 0.806452 \\
\hline Jammu \& Kashmir & 0.528 & 0.672 & 0.943 & 0.810484 \\
\hline Karnataka & 0.826 & 0.754 & 0.763 & 0.745968 \\
\hline Kerala & 0.842 & 0.94 & 1.000 & 1 \\
\hline Madhya Pradesh & 0.599 & 0.6956 & 0.577 & 0.556452 \\
\hline Maharashtra & 1.000 & 0.823 & 0.823 & 0.858871 \\
\hline Odisha & 0.474 & 0.729 & 0.562 & 0.596774 \\
\hline Punjab & 0.861 & 0.758 & 0.979 & 0.850806 \\
\hline Rajasthan & 0.671 & 0.661 & 0.869 & 0.705645 \\
\hline Tamil Nadu & 0.895 & 0.801 & 0.928 & 0.814516 \\
\hline Uttar Pradesh & 0.418 & 0.677 & 0.617 & 0.556452 \\
\hline West Bengal & 0.755 & 0.763 & 0.778 & 0.802419 \\
\hline Source: As & & & \\
\hline
\end{tabular}

Source: As Stated in the Above Table A2 